\title{
Knowledge Management and Industry 4.0 and Open Innovation
}

Gestión del Conocimiento e Industria 4.0 e Innovación Abierta

Gestão do Conhecimento e Indústria 4.0 e Inovação Aberta

\author{
José Ignacio Palacios Osma ${ }^{1}$ \\ Fabian Leandro Moreno Salazar ${ }^{2}$ \\ Karen Natalia Morales Gómez ${ }^{3}$
}

Received: January $18^{\text {th }}, 2020$

Accepted: March $30^{\text {th }}, 2020$

Available: May $4^{\text {th }}, 2020$

How to cite this article:

J. I. Palacios Osma, F. L. Moreno Salazar, K. N. Morales Gómez, "Knowledge Management and Industry 4.0 and Open Innovation," Revista Ingeniería Solidaria, vol. 16, no. 2, 2020. doi: https://doi.org/10.16925/2357-6014.2020.02.09

Artículo de investigación. https://doi.org/10.16925/2357-6014.2020.02.09

1 Facultad de Ingeniería - Universidad Distrital Francisco José de Caldas

ORCID: https://orcid.org/0000-0003-4701-4373

E-mail: jpalacios@udistrital.edu.co

2 Facultad de Ingeniería - Universidad Distrital Francisco José de Caldas

ORCID: https://orcid.org/0000-0003-4701-4373

E-mail: flmorenos@correo.udistrital.edu.co

3 Facultad de Ingeniería - Universidad Distrital Francisco José de Caldas

ORCID: https://orcid.org/0000-0003-0260-0790

E-mail:knmoralesg@correo.udistrital.edu.co 


\section{Abstract}

Introduction: The bibliographic review that is presented is the result of the research "Open Innovation and Knowledge Management" developed at the Universidad Distrital Francisco José de Caldas, during the year 2019; where the research problem focused on establishing the relationship between Open innovation, Knowledge management and its impact on Industry 4.0, where the exchange of information and knowledge is evident, allowing for the exchange and integration of knowledge and technology in the context of co-creation in Industry 4.0.

Objective: To demonstrate a Knowledge management and Industry 4.0 model that consolidates innovation processes in Colombian organizations.

Methodology: A systematic mapping of information was developed, focused on the academic databases of the publications that link the concepts of Knowledge management, Industry 4.0 and Open innovation in the period 2016-2019.

Conclusions: Innovation is a key factor for organizations, in particular to achieve competitiveness. For this, it is necessary to have inter-institutional and intra-institutional knowledge management models, characterized by the decentralized exchange of information in the context of Industry 4.0. Therefore, it is necessary that the governance of an organization understand and facilitate the processes of opening and exchanging knowledge and information.

Originality: This model allows for the convergence of different models of administration and organization management, which must be co-managers of resource management and human talent.

Limitations: The model is developed from the literature review and from the experiences presented in these investigations, implying that a second stage is necessary for validation with experts.

Key words: Knowledge Management; Industry 4.0; Human talent; Psychosocial environment; Open Innovation.

\section{Resumen}

Introducción: La revisión bibliográfica que se presenta, es el resultado de la investigación "Innovación Abierta y Gestión del Conocimiento" desarrollada en la Universidad Distrital Francisco José de Caldas, durante el año 2019, donde el problema de investigación se centra en establecer la relación entre innovación abierta, gestión de conocimiento y su impacto en la industria 4.0 donde es evidente el intercambio de información y conocimiento, que permite el intercambio e integración de conocimiento y tecnología en el contexto de la co-creación en la industria 4.0.

Objetivo: Presentar un modelo de integración gestión de conocimiento e industria 4.0 que permita consolidar procesos de innovación en las organizaciones colombianas.

Metodología: Se desarrolló un mapeo sistemático de información, centrado en las bases de datos académicas de las publicaciones que vincula los conceptos de gestión de conocimiento, Industria 4.0 e Innovación Abierta en el periodo 2016-2019.

Conclusiones: La innovación es un factor clave para las organizaciones y en particular para lograr su competitividad, para ello se debe contar con modelos de gestión de conocimiento interinstitucional e intrainstitucional, marcada por el intercambio descentralizado de información en el contexto de la industria 4.0, para ello se requiere que la gobernanza de la organización comprenda y facilite los procesos de apertura e intercambio de conocimiento e información.

Originalidad: El presente modelo permite la convergencia de diferentes modelos de administración y gestión de la organización, los cuales debe ser co-gestores en la gestión de recursos y talento humano. 
Limitaciones: El modelo se desarrolla a partir de la revisión bibliográfica realizada y de las experiencias presentadas en dichas investigaciones, lo cual implicaría una segunda etapa que permita validar el mismo con expertos.

Palabras clave: gestión del conocimiento; industria 4.0; talento humano; entorno psicosocial; innovación abierta.

\section{Resumo}

Introdução: A revisão bibliográfica apresentada é o resultado da pesquisa "Inovação Aberta e Gestão do Conhecimento", realizada na Universidade do Distrito Francisco José de Caldas, durante o ano de 2019, onde o problema da pesquisa se concentra em estabelecer a relação entre inovação aberta, gestão do conhecimento e seu impacto na indústria 4.0, onde a troca de informações e conhecimentos é evidente, permitindo o intercâmbio e a integração de conhecimento e tecnologia no contexto da co-criação na indústria 4.0.

Objetivo: Apresentar um modelo de gestão do conhecimento e integração da indústria 4.0 que permita consolidar os processos de inovação nas organizações colombianas.

Metodologia: Foi desenvolvido um mapeamento sistemático das informações, focado nas bases de dados acadêmicas das publicações que vinculam os conceitos de gestão do conhecimento, Indústria 4.0 e Inovação Aberta no período 2016-2019.

Conclusões: A inovação é um fator essencial para as organizações e, em particular, para alcançar sua competitividade, devendo possuir modelos de gestão do conhecimento interinstitucionais e intrainstitucionais, marcados pela troca descentralizada de informações no contexto da Indústria 4.0, por Isso requer que a governança da organização entenda e facilite os processos de abertura e troca de conhecimentos e informações.

Originalidade: Este modelo permite a convergência de diferentes modelos de administração e gestão da organização, os quais devem ser co-gerentes na gestão de recursos e talento humano.

Limitações: 0 modelo é desenvolvido a partir da revisão bibliográfica realizada e das experiências apresentadas nas referidas investigações, o que implicaria uma segunda etapa que permite sua validação com especialistas.

Palavras-chave: gestão do conhecimento; indústria 4.0; talento humano; ambiente psicossocial; inovação aberta.

\section{Introduction}

Knowledge Management is a process in which all the individuals of an organization intervene, both in the generation and in the transfer of knowledge. For this, there are different applicable models that manage emotional capital generated in the organization, both structural and relational, to enhance and structure good practices and help learn from mistakes. A pre-requisite to this creation, dissemination and use of knowledge, through structuring or cycles, is the capacity to absorb knowledge and subsequently develop the capacity for dissemination [1], taking advantage of the knowledge transfer between the different actors that are currently part of the 
production and service creation processes; a transition from an individual and centralized vision to a collaborative approach and integration of organizational capacities with others [2], promoting Open Innovation processes [3, 4].

On the other hand, Industry 4.0, understood as the next industrial revolution, currently plays an important role, both due to the technological developments that it demands (Smart sensors, Internet of Things, Cloud Computing, Service Internet, People's Internet, among others), such as taking advantage of large amounts of easily accessible information to process and extract trends and projections that improve processes and operations in organizations, as well as the integration of the physical and virtual world that will enhance production processes and smart products, therefore facilitating the decentralization of processes and human talent $[5,6]$.

In this information flow and knowledge generation process, just like with Industry 4.0 that seeks to generate efficiency in an organization's processes, we propose a model that relates these two concepts and integrates them as a model applicable to an organization, this being the main purpose of this article. Additionally, this process of exchanging knowledge and technology favors Open Innovation processes, which in turn feeds back into the processes of Industry 4.0.

In the development of this research work, the methodology of Systematic Literature Mapping was used, which provides an understanding of the state of the art from previous works related to the topic [7, 8], and subsequently leads to a proposed model that associates Knowledge Management with Industry 4.0. For this, the article begins by describing the methodology, then the definition of Knowledge Management, going through the description of Industry 4.0 and closing with the integration model for Industry 4.0 and Knowledge Management (I4.GC).

\section{Methodology}

Given the need to support the research, a bibliographic review is carried out in the Web of Science (WoS) and Scopus databases. This review is carried out with the aim of obtaining the most relevant information with regards to the field of study. The consultations on the research topics followed the systematic mapping methodology that consists of classifying, analyzing and identifying information on trends, authors, leading journals, etc. (Figure 1) 


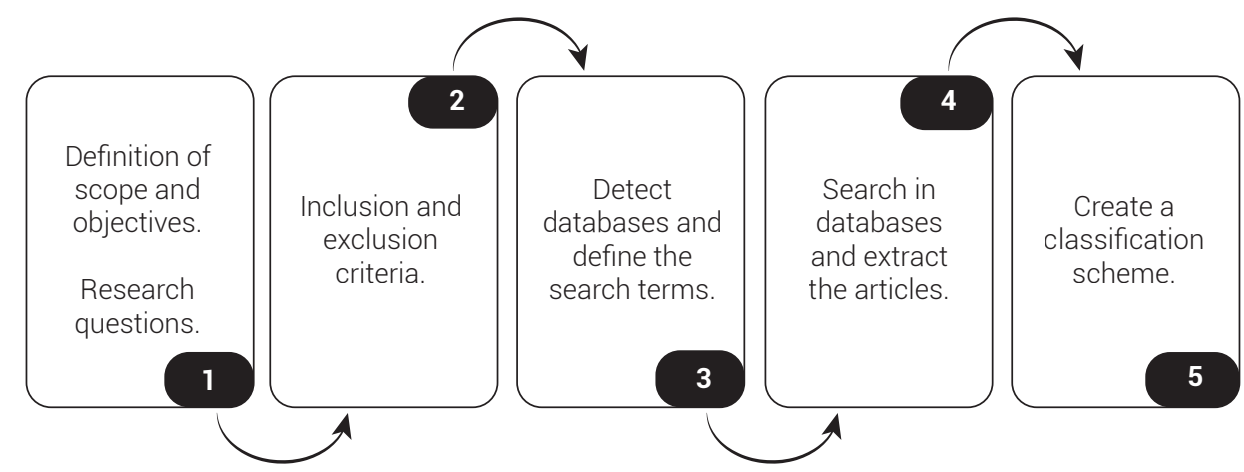

Figure 1. Systematic Mapping Protocol

Source: [7]

\subsection{Systematic search in databases}

In the first phase, the research objective was defined and the consultation criteria were defined. The extraction of articles was carried out and finally they were studied. Two search criteria were used; "Knowledge Management and Industry 4.0" and "Open Innovation and Industry 4.0". Only those articles under the type of access "Open access" were studied.

In Scopus, the search was limited to the categories "Engineering", "Business, Management and accounting" and "Computer science", given the relevance of the research. Similarly, in WoS the results were limited to "Management", "Business", "Industrial Engineering" and "Computer science information systems". For each of the databases consulted, the search code shown in Table 1 was generated. It should be noted that the search was not limited to a specific time period, for this reason all the results obtained are those existing to date (January 2020). 


\section{Table 1. Database search codes}

\begin{tabular}{|c|c|}
\hline Scopus & Web of Science \\
\hline \multirow{4}{*}{$\begin{array}{l}\text { TITLE-ABS-KEY (knowledge AND manage- } \\
\text { ment AND industry 4.0) AND DOCTYPE (ar } \\
\text { OR re) AND (LIMIT-TO (ACCESSTYPE(OA) ) } \\
\text { ) AND ( LIMIT-TO ( SUBJAREA, "BUSI") OR } \\
\text { LIMIT-TO ( SUBJAREA, "COMP")) }\end{array}$} & SUBJECT: (Knowledge management and industry 4.0) \\
\hline & $\begin{array}{l}\text { Refined by: OPEN ACCESS: (ALL OPEN ACCESS ARTICLES) AND } \\
\text { WEB OF SCIENCE CATEGORIES: (MANAGEMENT OR ENGINEE- } \\
\text { RING INDUSTRIAL OR BUSINESS OR COMPUTER SCIENCE } \\
\text { INFORMATION SYSTEMS ) AND TYPE OF DOCUMENTS: (ARTICLE } \\
\text { OR REVIEW) }\end{array}$ \\
\hline & Index=SCI-EXPANDED, SSCI, A\&HCl, ESCl \\
\hline & Period of time=EVERY YEAR \\
\hline \multirow{4}{*}{$\begin{array}{l}\text { TITLE-ABS-KEY (open innovation AND } \\
\text { industry 4.0) AND DOCTYPE (ar OR re) } \\
\text { AND (LIMIT-TO (ACCESSTYPE(OA) )) AND ( } \\
\text { LIMIT-TO ( SUBJAREA, "BUSI") OR LIMIT-TO } \\
\text { ( SUBJAREA, "COMP")) }\end{array}$} & SUBJECT: (Open innovation and industry 4.0) \\
\hline & $\begin{array}{l}\text { Refined by: OPEN ACCESS: (ALL OPEN ACCESS ARTICLES) AND } \\
\text { WEB OF SCIENCE CATEGORIES: (MANAGEMENT OR ENGINEE- } \\
\text { RING INDUSTRIAL OR BUSINESS OR COMPUTER SCIENCE } \\
\text { INFORMATION SYSTEMS) AND TYPE OF DOCUMENTS: (ARTICLE } \\
\text { OR REVIEW) }\end{array}$ \\
\hline & Index=SCI-EXPANDED, SSCI, A\&HCI, ESCl \\
\hline & Period of time=EVERY YEAR \\
\hline
\end{tabular}

Source: own work

The findings of the databases, based on the defined criteria, are those shown in Figure 2. 43 research articles were obtained in Scopus and 23 in WoS with the criteria of "Knowledge Management and Industry 4.0"; while for "Open Innovation and Industry 4.0" 17 articles were obtained in Scopus and 12 in WoS. It is important to mention that the search was also limited to "Research" and "Review" articles.

As can be seen in Figure 2, articles that relate to the concepts of Knowledge Management and Industry 4.0 appear since 2016 in the two main databases consulted.

Articles published under the concept "Knowledge management and Industry 4.0"

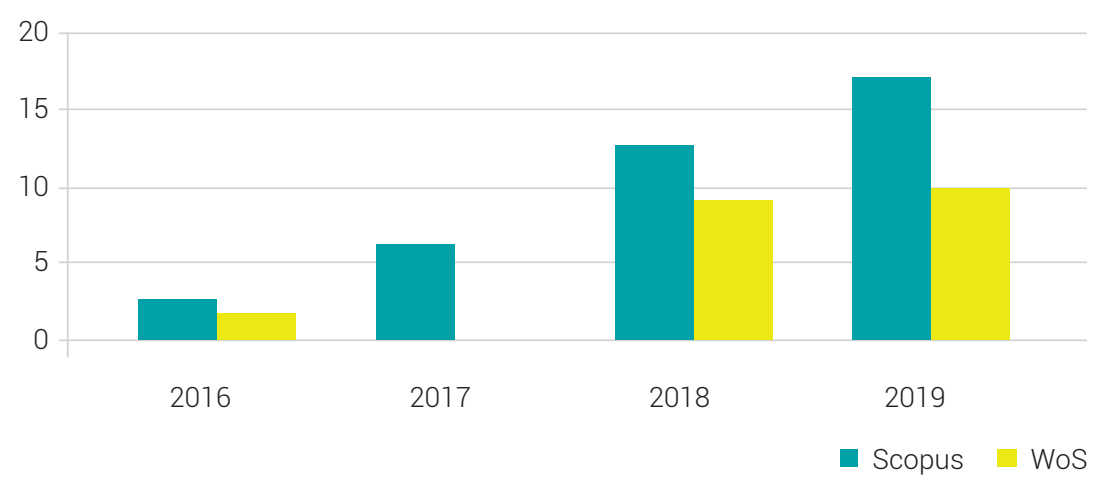

Figure 2. Publications of articles on Knowledge Management and Industry 4.0 Source: own work 
As evidenced in Figure 3, the studies carried out on these topics have been growing from 2016 to date, which shows the interest and relevance in the relationship of these concepts; not only in terms of their implications, but also in the contribution they make to the development of the productive and service sector.

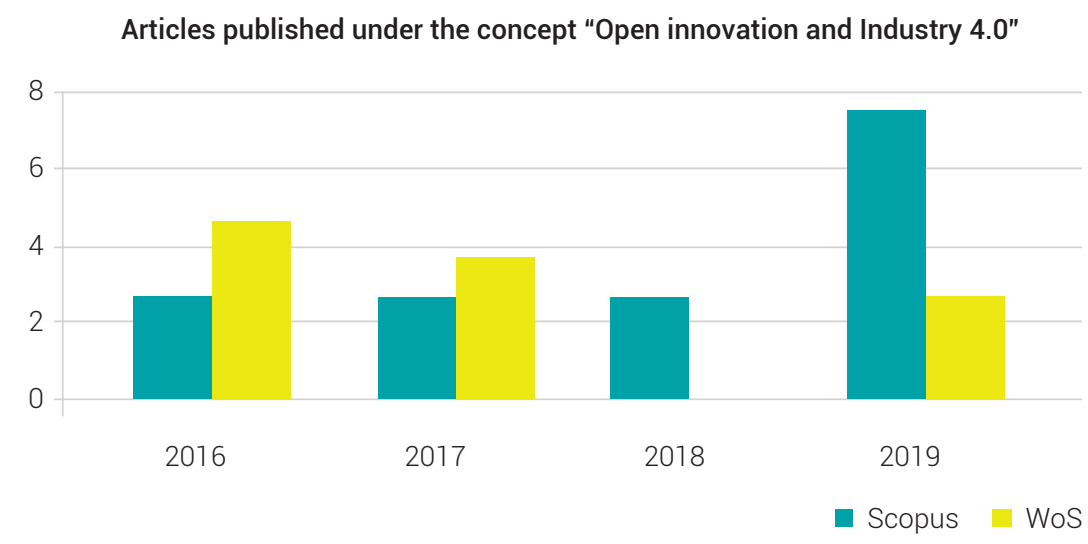

Figure 3. Publications of articles on Open Innovation and Industry 4.0 Source: own work

Of the 95 articles in total, it is worth mentioning that 6 of them are published in the two databases consulted, but what really stands out are 3 articles found in the two consultations carried out; both in $\mathrm{KM} \& \mathrm{I4}$, and in $\mathrm{OI} \& \mathrm{I4}$. One of these is an application where the factors that influence the adoption of Smart farming are discussed, and the other two talk about the generation and commercialization of knowledge for the industry from the relationship between the government and the HEIs (Higher Education Institutions), as well as the social and technical challenges involved in this knowledge transmission.

In this way, only $3 \%$ of the articles published in the consulted databases reflect a relationship between the concepts of Knowledge Management, Industry 4.0 and Open Innovation, making it very clear that it is a field that still has a lot to explore and supports the proposed final model.

As a second phase, once the research had been carried out, the articles were also analyzed and studied with the aim of being able to extract models, schemes or figures in which the authors present the link between Knowledge Management and Industry 4.0, as well as between Open Innovation and Industry 4.0. The different ways in which the authors present the connection between these research axes assume that Industry 4.0 requires work in conjunction with Knowledge Management and Open Innovation given the constant flow of two-way information (machine - person / 
company), making this a collaborative and cyclical process that involves all areas of a company.

Based on these findings, the proposed integration model is developed that contemplates people, resources, information and all those elements that represent the innovation of Industry 4.0 and the role of Knowledge Management in this new business paradigm.

\section{Theorical framework}

In Knowledge Management, there are different application models and methodologies, as well as the research carried out with respect to Industry 4.0, which has desirable application models and requirements, as well as capabilities that facilitate the implementation of Industry 4.0 in an organization.

\subsection{Knowledge Management}

Knowledge Management has been defined by Nonaka and Takeuchi as "a facilitating system for the search, codification, systematization and dissemination of the individual and collective experiences of the organization's human talent, to turn them into globalized knowledge, of common understanding and useful in carrying out all of its activities, to the extent that it allows generating sustainable and competitive advantages in a dynamic environment" [9], that is, Knowledge Management is the administration, identification, optimization and dynamic management of intellectual assets by individuals or communities [10, 11].

Nonaka and Takeuchi developed a Knowledge Management model in which they explain the creation of knowledge within organizations through a dynamic and constant mechanism of interaction or relationship between tacit knowledge and explicit knowledge that is built as the basis of the model as shown in Figure 4. Tacit knowledge refers to the knowledge that each individual possesses within them, and the explicit knowledge that refers to what can be represented or expressed through physically storable symbols that can be transmitted [12]. 


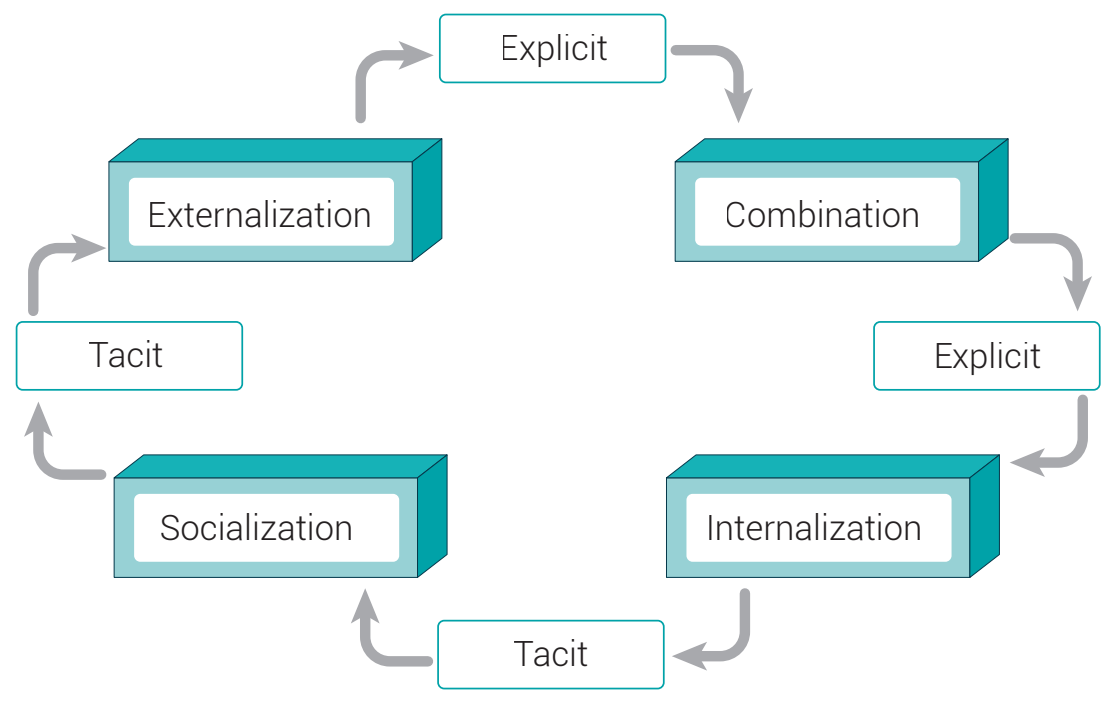

Figure 4. Nonaka model Source: [9]

According to this model (Fig. 4), the authors propose four processes in which the conversion of knowledge is generated [9]:

- Socialization is the process of acquiring, in which the tacit understanding of tacit knowledge is shown. That is, it is the passage from 'tacit knowledge that is already possessed' to 'other tacit knowledge'.

- Externalization is the process of converting tacit knowledge to explicit knowledge, through some kind of support that allows others to know it.

- Combination is the process of creating, it is the passage from explicit knowledge to explicit knowledge.

- Internalization is the process of incorporation. It is when you go from explicit knowledge to tacit knowledge. That is, when you internalize something, you read or observe and make it yours.

In this sense, the same Knowledge Management in the face of Open Innovation implies that said exchange of knowledge not only takes place within the organization but with other organizations, thus facilitating the exchange of knowledge and technologies $[13,14]$.

On the other hand, Andersen's KMAT model, cited by Patiño [15], proposes a model that focuses on facilitating the flow and transmission of important information that members of the organization have, how they receive it from them and how it 
returns to them again, with the aim of generating benefits or added value for customers. This model is shown in Figure 5.

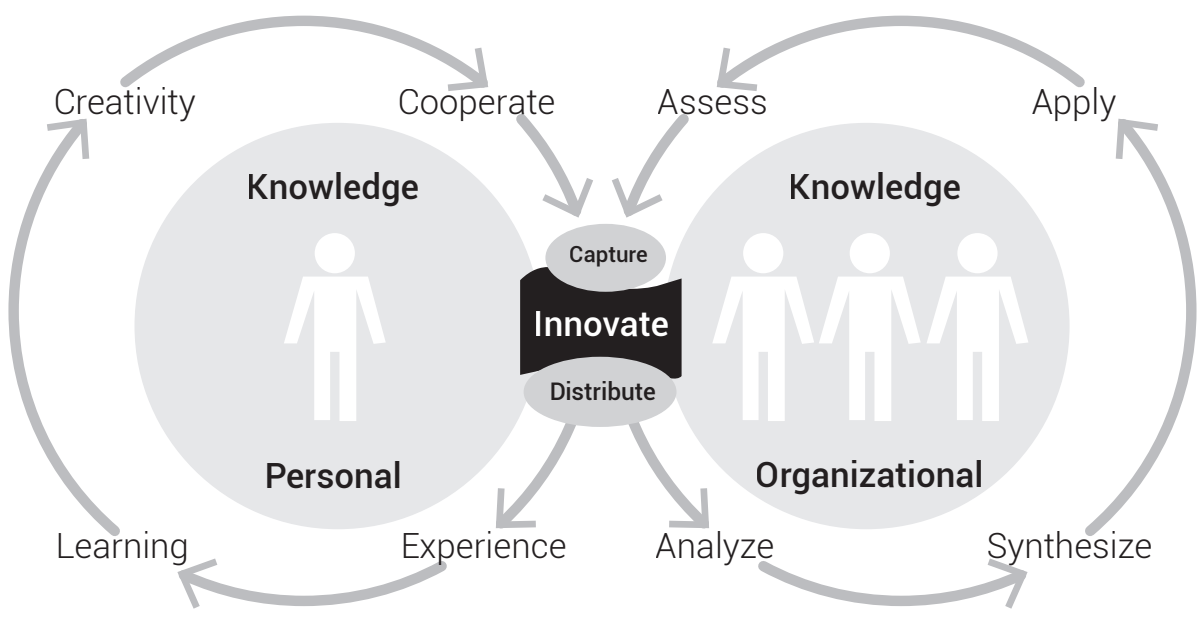

Figure 5. Arthur Andersen's Knowledge Management Model Source: [15]

Arthur Andersen recognizes the need to accelerate the flow of valuable information, from individuals in the organization and back to individuals, so that they can use it to create value for customers $[16,17]$.

From the individual point of view, it is the responsibility of each person to share and make explicit the knowledge for the organization; from the organizational point of view, it is the responsibility of creating the support infrastructure so that it is individually effective, creating the processes, culture, technology and systems that allow for the capture, distribution, analysis, synthesis, application and valuation of knowledge [11], as shown in Figure 5.

To favor this flow of information, two mechanisms are established: one is networks for sharing knowledge, which are physical or virtual places where staff can share their experiences, allowing communication, learning, and the transfer of knowledge between persons. The second is packaged or encapsulated knowledge, through an internal system called the Arthur Andersen knowledge space, which has diverse documentation such as methodologies, experiences, examples, and which are available to the company members [18].

The previous organizational models of Knowledge Management have been developed over time with a clear objective; intellectual capital. In this research, firstly, the Knowledge Management model proposed by the administration experts, Nonaka and Takeuchi, stands out; they were the first to relate the performance of companies 
with their ability to create knowledge and use it to be competitive and stay current [16, 19]. It is important that organizations do not deviate from their management objectives of growth, profitability and durability, creating new products, methods and new organizational forms [20] without leaving aside how they generate knowledge, which is what makes previous creations possible. As mentioned by the authors in their work "The knowledge-creating organization", aspects such as intelligence and rationality can be clearly evidenced in its two conceptualizations of tacit and explicit knowledge, establishing a relationship between innovation, knowledge and competitiveness [21].

From here, intellectual capital takes on great weight. It has gone from a development model of the physical era, to one of the knowledge era, where the organization must be established as an open system in which there are large knowledge flows with the external environment [22]. Such flows turn out to be a key aspect and that is why authors such as Andersen focused their studies on these, discovering the need to strengthen and accelerate the information flows that have value; this, so that as knowledge is acquired, adapted and waiting to be transferred, it has an added value and its use can be promoted through the client. With this model, organizations begin to create clear strategies so that decision-making is closely related to or based on knowledge and with a clear objective, competitiveness, established as a measure of comparing the performance of the organization; such performance being defined in terms of profitability compared to other organizations.

These two models are then the basis of the present investigation, given their objective of managing intellectual capital so that, in a holistic way, it achieves the creation of knowledge by accelerating the flow of information in organizations. Both approaches clearly allow the integration of people and machines, which is the ultimate goal of Knowledge Management in this new technological and industrial era.

\subsection{Industry 4.0}

Also known as the fourth industrial revolution, Industry 4.0 exposes the way in which factory organization goes from being hierarchical to being totally decentralized thanks to automation, digitization and the massive exchange of information via the internet, particularly due to the capacity to extract data from monitored assets $[23,24]$. The main promoter of this concept has been Germany, who in 2011 at the Hannover Messe fair [25] coined the word "Industry 4.0", which is also known as "Smart Industry".

Organizations must have the capacities to face the changes that Industry 4.0 entails, and for this, Dan Li defines four structural areas of business that must be treated with caution and allow for the measurement of the maturity of the company 
in this process $[26,27]$ : Resources, Information Systems, Organizational Structure and Culture. This digitization paradigm consists of computerization and connectivity, based on IT systems to support the exchange of information and knowledge [28].

The business model must be aligned with the Industry 4.0 structure according to the functioning of the systems that will connect and share data in real time between all the links that make up the chain of an organization [29]. This implies a connection of people, objects and systems (Fig. 6).

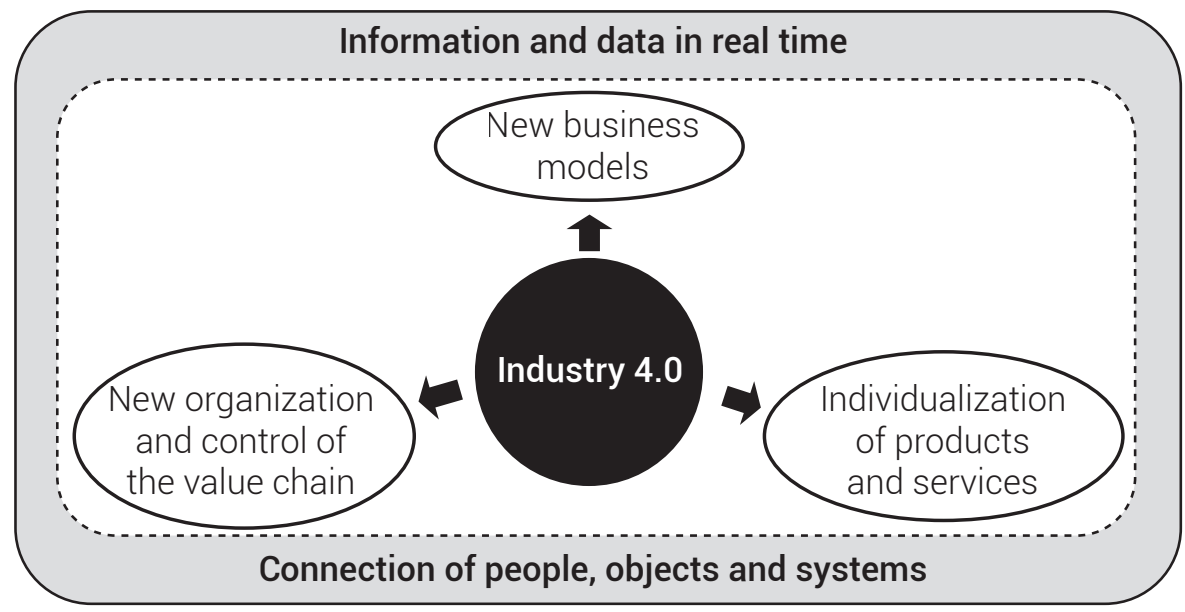

Figure 6. Simplified description of Industry 4.0 Source: [29]

The human factor is critical in Industry 4.0 as industrial automation also results in the "re-definition" of jobs, which is why educational development is recommended for the organization's employees. Avoiding islands of knowledge is one of the objectives of interconnectivity, and the sharing of knowledge requires that it must not remain within the limits of the organization, but must exceed them [30, 31].

It is therefore necessary to talk about Computer-Supported Collaborative Work (CSCW), so that it includes processes and resources that are being involved and offers an integration of tools and methods that support the collaboration of work teams and can potentially improve the productivity and effectiveness of those who work collaboratively $[32,33]$. The relevant issues involving Industry 4.0 are set out in Figure 7. 


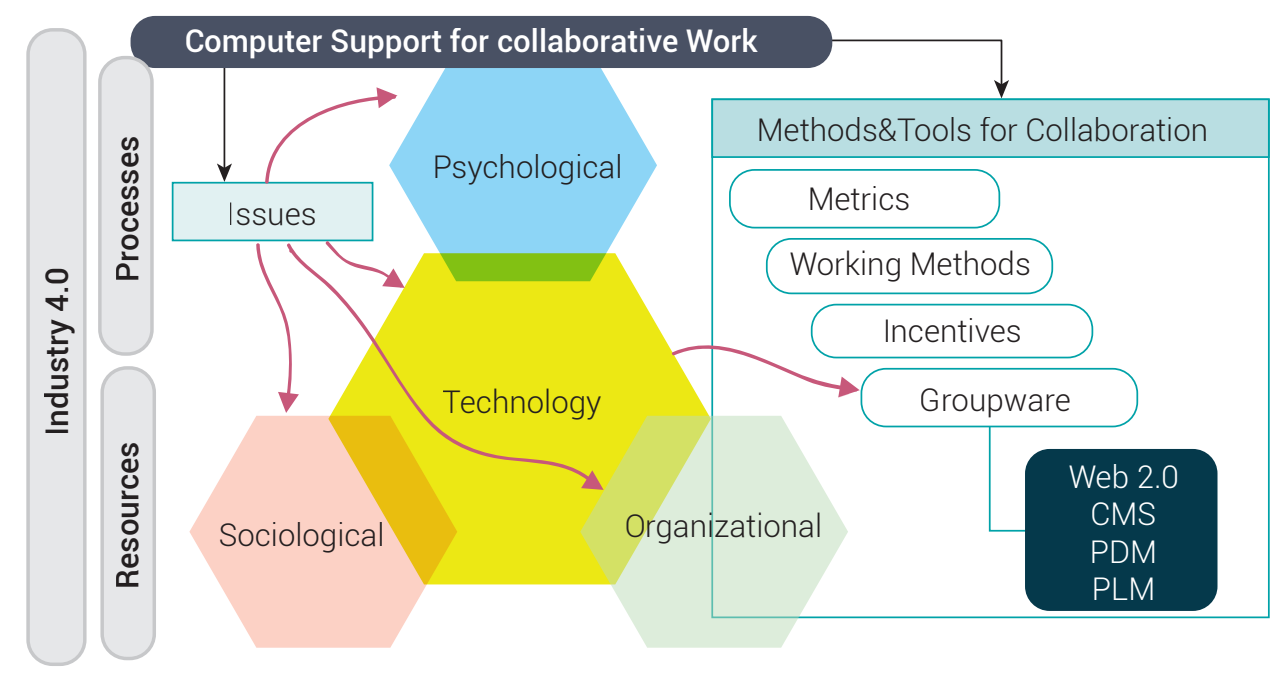

Figure 7. Methods, themes and tools in CSCW Source: [33].

These are all the factors to consider regarding Industry 4.0 and what it implies within Knowledge Management. Requirements, capacities and restrictions have to be considered in what experts call the fourth industrial revolution.

\section{Open Innovation}

Open Innovation (OI) is the creation and establishment of new processes in organizations, which allow them to face the challenges of globalization and see $\mathrm{Ol}$ as a good alternative for it [34-36]. They demonstrate the importance of motivation and interest in the exchange of information and of the cooperation of the parties to create new processes [37]. In this sense, three dimensions are identified as essential factors that help in determining if an organization is motivated to take advantage of Open Innovation (Fig. 8): 


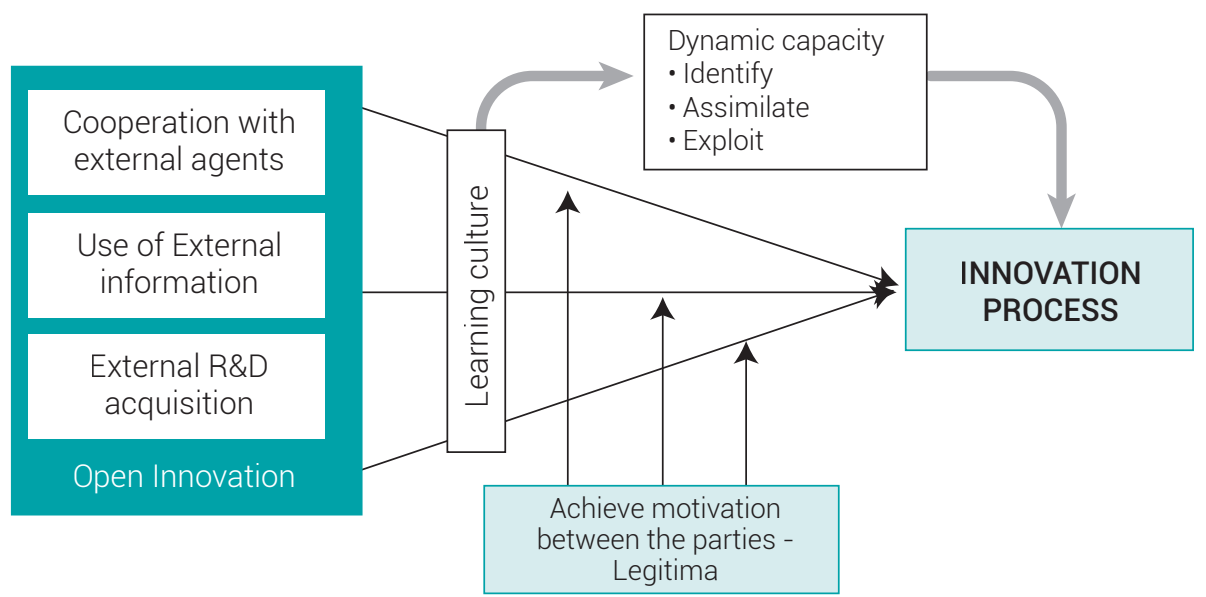

Figure 8. Innovation processes - Created from Source: [35]

It should be borne in mind that for such an innovation process to be achieved, access to resources or the motivation of those involved is not enough; it is also necessary to enhance the dynamic capabilities of the organization, which are what allow it to identify, assimilate and exploit or improve organizational performance [38, 39].

\section{Results}

Interconnectivity, collaboration, information flow, knowledge, networks, people, technology, etc., are some of the many concepts that interrelate when talking about Knowledge Management in companies that use or try to apply Industry 4.0, given that this breaks the paradigm of keeping information purely for company processes; this is why organizational change must be managed, from its philosophy to its processes, and the way information is managed [40].

For an organization to be successful in the environment of Industry 4.0, it must pay attention to the training, learning and Knowledge Management processes [41]. In this way, the uncertainty and the changing environments typical of organizations can be optimally managed. The organizational structure is another key point in the development of a work environment that promotes innovation and learning.

Open Innovation is now conceived from a network perspective and highlights the importance of relying on external sources and information feedback processes generated by Industry 4.0. Hence, some authors speak of Open Innovation 2.0 [42] in which they identify that shared value depends on social, economic and productive conditions, from sustainable and prosperous models $[43,44]$. 


\section{Proposed model}

As a result of this analysis and based on the findings of the queries made in the databases, the state of the research topic allows us to define a series of nodes, criteria and participants who integrate these two broad concepts into the field of research; Knowledge Management is therefore the main source of innovation and achieving the correct administration of the large volumes of information promoted by Industry 4.0 is a complex and repetitive task that must be carried out continuously to achieve continuous improvement in the development process and implementation and evaluation of the same.

The basis of the proposed model is in people and technology, since it is from, to and through these that information flows and must be managed in the best way in order to create more knowledge and strengthen the intangible assets that organizations possess [45]. From there, two key concepts emerge, such as information and connectivity, which for obvious reasons are closely linked, giving a circular process in which one leads to the other and vice versa [17].

The data that arises in a production process is enormous and never stops flowing, so the proposed model represents a continuous flow of all the key actors and concepts that are involved; always under the concept of innovation and Knowledge Management [46]. Figure 9 formulates the framework of what Industry 4.0 is, so that everything is aligned for effective communication between all the actors that make up an organization, including external actors.

Knowledge Management based on openness (collaboration) creates a network through which the other processes that allow for the expected change are supported; through the collaborative work of the technological platforms present in Industry 4.0. This is how people and information systems (computer and control equipment) are the basis of the entire system, and it is they who are responsible for keeping the organization moving under the criteria of knowledge creation. Systemic knowledge is that which starts with the interaction of technology, the system and computer equipment, to strengthen the intelligence that physical resources are capable of creating. On the other hand, data analysis, connectivity and computer equipment are related to the extent that they facilitate the creation of real-time knowledge, which is finally the characteristic knowledge of Industry 4.0, the speed of information and the immediate instant. 


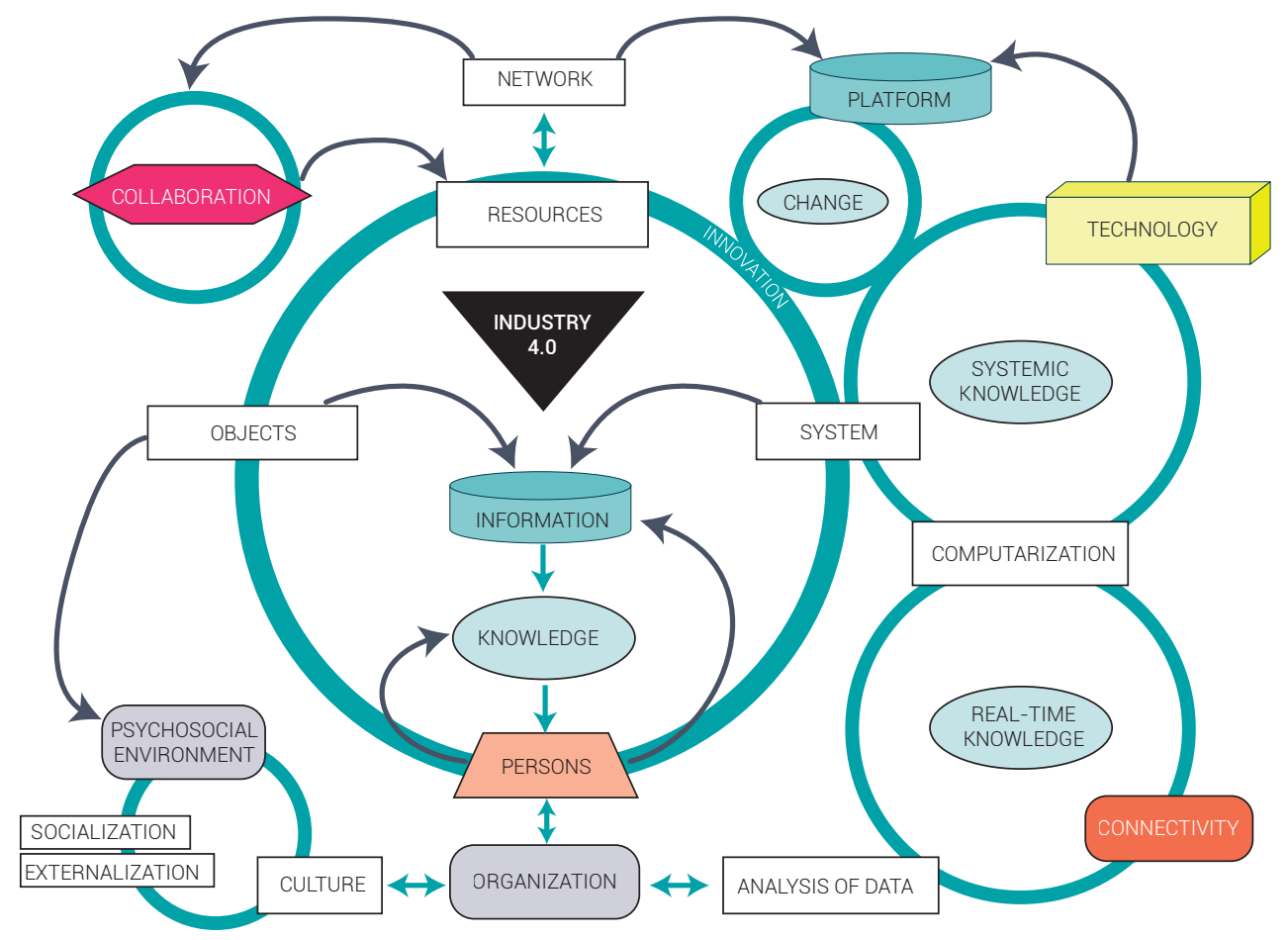

Figure 9. Knowledge Management and Industry 4.0 Integration Model Source: own work

Regarding collaborators, they all have the main role because knowledge is managed thanks to them, but this is achieved to the extent that they are able to adapt to the changes that Industry 4.0 requires. Environment and culture are therefore the key factors in this relationship [47]. They allow for the effective communication of the tacit and explicit knowledge that is in the organization's domains, in order to be able to share and work in collaboration with other companies in the future, thus avoiding undesirable islands of information [48]. Resources and objects are the basic needs of any organization and in this case they cannot be left out of the model; these include high-tech sensors, as the factor of the monetary resource, since the process of implementing Industry 4.0 requires a high economic investment, but it promises a very high retribution and significant competitive advantages.

Organizational change is based on employee-machine-product integration, needing a re-conception of their roles within the company [49]; and it is here that the human factor becomes critical, to the extent that constant training and education is needed to motivate collaborators to facilitate change, so that they can be motivated to collaborate with the new needs and challenges that Industry 4.0 entails. 
Requirements, skills and qualifications are required or recommended for both individuals and teams that are in the process of adopting Industry 4.0 and promoting Knowledge Management as an advantage to save resources and time, and encourage simplicity and knowledge [50]. Technology must be a facilitator but not a solution, and that is why, in the case of information systems and equipment, they must possess skills for information management through statistics, data processing and business intelligence [51]. On the other hand, for people, it is necessary to posess teamwork skills, a readiness and adaptability to change, and social and communication skills in order to generate a continuous and effective flow of information that allows for the creation and subsequent management of knowledge.

\section{Conclusions and Discussion}

Knowledge Management models are complemented by the fourth industrial revolution in terms of the flow of information and the generation of knowledge from this. In the same way, the processes that are evident in the models presented are related to the process of generating innovation in organizations, such as the use of technology and the fact of sharing both individual and organizational knowledge.

Knowledge creation comes from two sources, from organizations and the need to solve a problem, so the Nonaka \& Takeuchi knowledge creation model continues to be in force and applicable to the extent that links are created with other organizations such as universities and the government. This encourages the flow of knowledge in an externalizing and internalizing manner, thus complementing the proposed model (Fig. 10).

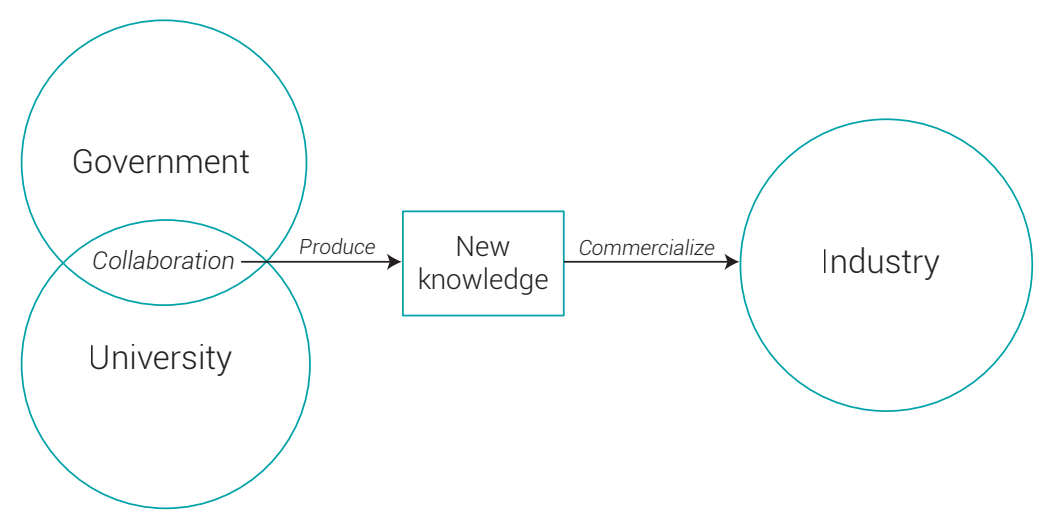

Figure 10. Integrated knowledge creation model in the industry

Source: [52] 
It is the power of organizations to define the extent to which they consider the inter-institutional collaborative level optimal, since it may violate the limits of confidentiality established by the organizations. It is here that the concept of Open Innovation is integrated, which according to Chesbrough (the main speaker on the topic), consists of having the ability to commercialize internally developed ideas and acquire ideas from external companies in order to generate value for organizations [53].

It is outlined with a porous environment that allows for the input and output of organizations working in collaboration. In order to carry out this process, both the internal factors of the company and the factors intrinsic to the industry in which the company operates must be taken into account [14], since a series of dynamic capacities are required to achieve this objective, and this is another level of commitment and skills that must go hand in hand with the implementation of Industry 4.0 in organizations.

\section{Future research}

For future research, the key concepts that make up the model are Open Innovation and Collaborative Integration between government, academia and industry. In this way, the proposal presented here is strengthened, broadening the spectrum of application and getting closer and closer to the reality that organizations that are in the process of adaptation, or have the idea of adapting the fourth industrial revolution, must face.

For those who wish to continue researching the subject, it is recommended to delve deeper into systematic consultation to determine a more approximate level in terms of research in this area and, if possible, apply quality filters that guarantee the study of publications in journals with the highest categories (quartiles 1 and 2 for indexed journals), which was not applied in the present investigation.

\section{References}

[1] P. Veer Ramjeawon and J. Rowley, "Knowledge management in higher education institutions in Mauritius," International Journal of Educational Management, vol. 32, pp. 1319-1332, 2018. [Online]. doi: https://doi.org/10.1108/IJEM-05-2017-0129

[2] Q. Ai and H. Tan, "The intra-firm knowledge transfer in the outward M\&A of EMNCs: Evidence from Chinese manufacturing firms," Asia Pacific Journal of Management, vol. 35, pp. 399-425, Jun 2018. [Online]. doi: 10.1007/s10490-017-9518-z 
[3] Chesbrough $\mathrm{H}$, Open innovation: The new imperative for creating and profiting from technology: pp. 51 - 66. Harvard Business Press, 2003.

[4] H.Chesbrough, etal., "Value creation and value capture in open innovation," Journal of Product Innovation Management, vol. 35, pp. 930-938, 2018. [Online]. doi: https://doi.org/10.1111/ jpim. 12471

[5] M. Ghobakhloo, "The future of manufacturing industry: a strategic roadmap toward Industry 4.0," Journal of Manufacturing Technology Management, vol. 29, pp. 910-936, 2018. [Online]. doi: https://doi.org/10.1108/JMTM-02-2018-0057

[6] J. A. Saucedo-Martínez, et al., "Industry 4.0 framework for management and operations: a review," Journal of ambient intelligence and humanized computing, vol. 9, pp. 789-801, 2018. [Online]. doi: https://doi.org/10.1108/JMTM-02-2018-0057

[7] A. Garcia-Gonzalez and M. S. Ramirez-Montoya, "Systematic Mapping of Scientific Production on Open Innovation (2015-2018): Opportunities for Sustainable Training Environments," Sustainability, vol. 11, pp. 1781, 2019. [Online]. doi: https://doi.org/10.3390/su11061781

[8] K. L. James, et al., "A methodology for systematic mapping in environmental sciences," Environmental evidence, vol. 5, p. 7, 2016. [Online]. doi: https://doi.org/10.1186/ s13750-016-0059-6

[9] I. y. T. Nonaka, y Takeuchi, La organización creadora del conocimiento, pp, 61 - 103, OXFORD, 1999.

[10] S. A. Al Ahbabi, et al., "Employee perception of impact of knowledge management processes on public sector performance," Journal of Knowledge Management, vol. 23, pp. 351-373, 2019. [Online]. doi: https://doi.org/10.1108/jkm-08-2017-0348

[11] S. Devi Ramachandran, et al., "The practice of knowledge management processes: A comparative study of public and private higher education institutions in Malaysia," Vine, vol. 39, pp. 203-222, 2009. [Online]. doi: https://doi.org/10.1108/03055720911003978

[12] V. Lefter, et al., "Intergenerational knowledge transfer in the academic environment of knowledge-based economy," Amfiteatru Economic Journal, vol. 13, pp. 392-403, 2011. [Online]. Available: http://hdl.handle.net/10419/168725

[13] M.Raunio,etal.(2018,OpenInnovationPlatformsasaKnowledgeTrianglePolicyTool-Evidence from Finland. Форсайт $12(2$ (eng)). [Online]. Available: https://cyberleninka.ru/article/n/ open-innovation-platforms-as-a-knowledge-triangle-policy-tool-evidence-from-finland 
[14] M. S. Ramirez and F. J. Garcia-Penalvo, "Co-creation and open innovation: Systematic literature review," Comunicar, vol. 26, pp. 9-18, Jan 2018. [Online]. doi: https://doi.org/10.3916/ C54-2018-01

[15] S. G. Patiño, et al. (2008, Modelo de gestión del conocimiento apoyado en la vigilancia tecnológica y la inteligencia competitiva para la cadena productiva de la uva Isabella en la bioregión del Valle del Cauca. Cuadernos de Administración 24(40), 73-93. [Online]. Available: https://dialnet.unirioja.es/servlet/articulo?codigo=5006480

[16] B. A Rahman, et al. (2009, Knowledge management initiatives, innovation and GLC performance. Journal of Information and Communication Technology 8, 15-27. [Online]. Available: http://repo.uum.edu.my/292/

[17] A. M. Abubakar, et al., "Knowledge management, decision-making style and organizational performance," Journal of Innovation \& Knowledge, 2017/10/21/ 2017. [Online]. doi: https:// doi.org/10.1016/j.jik.2017.07.003

[18] S. G. Patiño, Mejía, M. S., \& Villarreal, M., "Modelo de gestión del conocimiento apoyado en la vigilancia tecnológica y la inteligencia competitiva para la cadena productiva de la uva Isabella en la bioregión del Valle del Cauca," Cuadernos de administración, vol. 24, 2011, pp. 73-93.

[19] D. Schartinger, et al., "Knowledge interactions between universities and industry in Austria: sectoral patterns and determinants," Research policy, vol. 31, pp. 303-328, 2002. [Online]. doi: https://doi.org/10.1007/3-540-35981-8_7

[20] R. Paul, et al., "Global virtual team performance: the effect of coordination effectiveness, trust, and team cohesion," IEEE Transactions on Professional Communication, vol. 59, pp. 186-202, [Online]. doi: 2016. https://doi.org/10.1109/TPC.2016.2583319

[21] L. Camarinha-Matos and H. Afsarmanesh, "Collaborative networks: Value creation in a knowledge society, (invited keynote paper)," IVI (FNWI), 2006. [Online]. Available: https://dare. uva.nl/personal/pure/en/publications/collaborative-networks-value-creation-in-a-knowledge-society-invited-keynote-paper(74edd512-3951-4bbf-8c1d-97382a059e54).html

[22] S. Reichert. (2019). The Role of Universities in Regional Innovation Ecosystems. [Online]. Available: www.eua.eu

[23] A. Diez-Olivan, et al., "Data fusion and machine learning for industrial prognosis: Trends and perspectives towards Industry 4.0," Information Fusion, vol. 50, pp. 92-111, 2019. [Online]. doi: https://doi.org/10.1016/j.inffus.2018.10.005 
[24] M. J. B. Rojas, et al., "Propuesta de una Arquitectura de la Industria 4.0 en la Cadena de Suministro desde la Perspectiva de la Ingeniería Industrial," Revista Ingenieria Solidaria, vol. 13, pp. 77-91, 2017. [Online]. doi: https://doi.org/10.16925/in.v23i13.2007

[25] A. Weckenmann, et al., "Hit or Miss? Evaluating the Potential of a Research Niche: A Case Study in the Field of Virtual Quality Management," Sustainability, vol. 11, p. 1450, 2019. [Online]. doi: https://doi.org/10.3390/su11051450

[26] D. Li, et al., "Current and future Industry 4.0 capabilities for information and knowledge sharing," The International Journal of Advanced Manufacturing Technology, vol. 105, pp. 39513963, 2019. [Online]. doi: https://doi.org/10.1007/s00170-019-03942-5

[27] N. T. Le and D. B. Hoang, "Capability Maturity Model and Metrics Framework for Cyber Cloud Security," Scalable Computing-Practice and Experience, vol. 18, pp. 277-290, Dec 2017. [Online]. doi: https://doi.org/10.12694/scpe.v18i4.1329

[28] D. Aloini, et al., "Implementing open innovation: conceptual design of an integrated ICT platform," Journal of Knowledge Management, vol. 21, pp. 1430-1458, 2017. [Online]. doi: https:// doi.org/10.1108/JKM-11-2016-0517

[29] G. A. Cordeiro, et al., "Theoretical proposal of steps for the implementation of the Industry 4.0 concept," Brazilian Journal of Operations \& Production Management, vol. 16, pp. 166-179, 2019. [Online]. doi: https://doi.org/10.14488/BJOPM.2019.v16.n2.a1

[30] K. Stachová, et al., "External partnerships in employee education and development as the key to facing industry 4.0 challenges," Sustainability, vol. 11, p. 345, 2019. [Online]. doi: https://doi. org/10.3390/su11020345

[31] A. L. Mention, "Co-operation and co-opetition as open innovation practices in the service sector: Which influence on innovation novelty?," Technovation, vol. 31, pp. 44-53, Jan 2011. [Online]. doi: https://doi.org/10.1016/j.technovation.2010.08.002

[32] J. J. Yun and Z. Liu, "Micro- and macro-dynamics of open innovation with a Quadruple-Helix model," Sustainability (Switzerland), vol. 11, 2019. [Online]. doi: https://doi.org/10.3390/ su11123301

[33] C. Vila, et al., "Project-based collaborative engineering learning to develop Industry 4.0 skills within a PLM framework," Procedia manufacturing, vol. 13, pp. 1269-1276, 2017. [Online]. doi: https://doi.org/10.1016/j.promfg.2017.09.050 
[34] A. Ferraris, et al., "Open innovation in multinational companies' subsidiaries: the role of internal and external knowledge," European Journal of International Management, vol. 11, pp. 452-468, 2017. [Online]. doi: https://doi.org/10.1504/ejim.2017.10006514

[35] C. Tsinopoulos, et al., "Process Innovation: Open Innovation and the Moderating Role of the Motivation to Achieve Legitimacy," Journal of Product Innovation Management, vol. 35, pp. 27-48, Jan 2018. [Online]. doi: https://doi.org/10.1111/jpim.12374

[36] H. Chesbrough, et al., New frontiers in open innovation: Oup Oxford, 2014.

[37] S.-Y. Perng, et al., "Hackathons, entrepreneurial life and the making of smart cities," Geoforum, 2018. [Online]. doi: https://doi.org/10.1016/j.geoforum.2018.08.024

[38] C. H. Yuan, et al., "Dynamic capabilities, subnational environment, and university technology transfer," Strategic Organization, vol. 16, pp. 35-60, Feb 2018. [Online]. doi: https://doi. org/10.1177/1476127016667969

[39] B. Ciao, "Dynamic capabilities' functioning in a private equity-backed firm," Strategic ChangeBriefings in Entrepreneurial Finance, vol. 27, pp. 23-33, Jan 2018. [Online]. doi: https://doi. org/10.1002/jsc.2177

[40] P. Adler and C. Heckscher, "The collaborative, ambidextrous enterprise," Universia Business Review, 2013. [Online]. Available: https://dialnet.unirioja.es/servlet/articulo?codigo $=4451433$

[41] S. Shamim, et al., "Examining the feasibilities of Industry 4.0 for the hospitality sector with the lens of management practice," Energies, vol. 10, p. 499, 2017. https://doi.org/10.3390/ en10040499

[42] M. Perkmann and K. Walsh, "University-industry relationships and open innovation: Towards a research agenda," International Journal of Management Reviews, vol. 9, pp. 259-280, 2007. [Online]. doi: https://doi.org/10.1111/j.1468-2370.2007.00225.x

[43] M. Porter and M. Kramer, "La creación de valor compartido," Harvard Business Review, vol. 89, pp. 32-49, 2011. [Online]. doi: https://doi.org/10.1111/j.1468-2370.2007.00225.x

[44] M. Curley and B. Salmelin, "Open Innovation 2.0: a new paradigm," OISPG White Paper, pp. 1-12, 2013. [Online]. Available: https://uc-dk.dk/uasnet/wp-content/uploads/Open-Innovation2.0-Salmelin.pdf 
[45] E. C. Mayo, et al., "Knowledge transfer from the innovative university. A model of information management in the digital context: the PIEDD case study," Revista Latina De Comunicacion Social, vol. 74, pp. 537-553, 2019. [Online]. doi: https://doi.org/10.4185/rlcs-2019-1344-27

[46] S. Najafi-Tavani, et al., "How collaborative innovation networks affect new product performance: Product innovation capability, process innovation capability, and absorptive capacity," Industrial Marketing Management, vol. 73, pp. 193-205, 2018. [Online]. doi: https://doi. org/10.1016/j.indmarman.2018.02.009

[47] G. Wang, et al., "An Integrated Open Approach to Capturing Systematic Knowledge for Manufacturing Process Innovation Based on Collective Intelligence," Applied Sciences, vol. 8, p. 340, 2018. [Online]. doi: https://doi.org/10.3390/app8030340

[48] J. Vega Jurado, et al. (2010, coreion with scientific agents and firm's innovative performance. Ingenio, Comunicaciones congresos, Spain. Available: http://hdl.handle.net/10261/26695

[49] A. Jerman, et al., "The Influence of Critical Factors on Business Model at a Smart Factory: A Case Study," Business systems research journal: international journal of the Society for Advancing Business \& Information Technology (BIT), vol. 10, pp. 42-52, 2019. [Online]. doi: https://doi.org/10.2478/bsrj-2019-0004

[50] J. J. Yun, et al., "Collective Intelligence: An Emerging World in Open Innovation," Sustainability, vol. 11, p. 4495, 2019. https://doi.org/10.3390/su11164495

[51] H. Karre, et al., "Transition towards an Industry 4.0 state of the LeanLab at Graz University of Technology," Procedia manufacturing, vol. 9, pp. 206-213, 2017. [Online]. doi: https://doi. org/10.1016/j.promfg.2017.04.006

[52] A. Abbas, et al., "University-government collaboration for the generation and commercialization of new knowledge for use in industry," Journal of Innovation \& Knowledge, vol. 4, pp. 23-31, 2019. [Online]. doi: https://doi.org/10.1016/j.jik.2018.03.002

[53] T. Kohler and H. Chesbrough, "From collaborative community to competitive market: The quest to build a crowdsourcing platform for social innovation," R\&d Management, vol. 49, pp. 356-368, 2019. [Online]. doi: https://doi.org/10.1111/radm.12372 